\title{
MICHAEL ANDERSON
}

\section{TRANSNATIONALE BARNDOMME}

\section{Refleksioner over børnemigranter og identitet}

En nyere strømning inden for antropologien ser det lokale og det globale som organiserende poler for social viden. Mellem disse poler kan man sige, at tingenes orden, mennesker, steder og processer bevæger sig frem og tilbage i dynamiske konstruktioner af kultur, kontekst og identitet (se Fardon 1995; Moore 1996). Væsentlige dele af denne dynamik er de globale markeders bevægelser og den flydende strøm af penge, ideer, tøj- og spisevaner osv. - for slet ikke at nævne diaspora, menneskevandringer, flygtninge og ekspatrioter, der har blandet og sammensat den postmoderne verdens kulturelle farveskala. Den tværfaglige interesse i menneskevandringer og migrationer har næret, og ladet sig nære af, lokal-globale perspektiver, og den har bibragt en stadigt voksende fornemmelse af, at den sociale og kulturelle bevægelighed tager til i styrke (jf. Hannerz 1996).

Børn og barndom har imidlertid været bemærkelsesværdigt fraværende i denne diskussion. Man kan hævde, at børn (i det mindste implicit) er en væsentlig del af diskussionen. Men i et fag, der har gjort det til sin opgave at drage kulturelle antagelser frem i lyset og fremvise netop det implicitte, er man ikke nået langt, hvad angår børn. Børnenes fravær eller nærmere deres usynlighed i diskussionen er ironisk, når man tænker på deres politiske „nærvær“ og opmærksomheden over for børn på et globalt niveau. Der findes organisationer som Unicef og „Børn i Nød“, som har gjort meget for at gøre opmærksom på børn som en overset social kategori såvel generelt som i specifikke geografiske områder (Ennew 1986; Boyden 1990). „Barnet“ som universelt billede er et magtfuldt, symbolsk fokus for medierne og den moralske opmærksomhed.

Først nu er forskelle på barndomme i forskellige kulturer blevet taget til efterretning og sat op imod globale processers homogeniserende tendenser inden for international ret og politik. Men disse forskelle fikseres i forhold til bestemte geografiske steder. Enten abstraheres børn ind i en global homogenitet, som i FN-dokumentet „The State of the World's Children“ 1987, hvor en ritualiseret opremsning af implicitte ,behov“ danner en universel social natur. Eller også fører kritik af en sådan homogenisering til det uundgåelige tilbagefald, at børn specificeres i forhold til kultur eller nation. Dertil kommer, at barndomme ikke blot anskues som statiske og polariserede; børn synes også frataget enhver form for evne til selv at konstruere perspektiver på lokale og globale ,positioner“.

På ét niveau er dette forståeligt. På et andet forekommer det nødvendigt særligt at fremhæve det globalt bevægelige, transnationale barn ikke blot som en kendsgerning i 
det lokale og globale liv, men også som en aktør i de sociale processer. Dette barn er et refleksivt væsen, der formår at gøre sig tanker om og udforme fortællinger om sine egne erfaringer med forandringer. Denne artikel beskæftiger sig med nogle irakiske migrantbørn og forsøger at vise, hvorledes de faktisk har perspektiver på sig selv som transnationale, og hvordan de kæmper for at udtrykke disse.

\section{Felt og metode}

Undersøgelsen baserer sig på et feltarbejde, der blev udført i et flygtningecenter i Athen. Det drives af det internationale religiøse selskab, Barmhjertighedens Missionærer, der er grundlagt af den nyligt afdøde Moder Theresa i Calcutta. Mit arbejde her bestod hovedsagelig i frivillig undervisning og opsyn med børnene. Centeret husede omkring 15 familier og fors $\emptyset$ gte ydermere at tilgodese behovene hos mange flere i det omkringliggende område. Flygtningefamilier fra Irak udgjorde flertallet af brugerne suppleret med enkeltpersoner fra Albanien, det tidligere Jugoslavien og Polen.

Den stadige strøm af familier, som flygter fra Iraks ubarmhjertige diktatur og dårlige $\emptyset$ konomiske situation, er fortsat siden tiden før Golfkrigen i 1991. Som Vestens bagdør repræsenterer Grækenland frihed og håb for mange migrantfamilier. De fleste bliver der ikke, men forsøger at komme videre til andre lande såsom Australien, Canada og USA eller til landene i Nordeuropa. Det lykkes til sidst for en del familier, selvom mange har måtte vente temmelig længe på deres endelige ,godkendelse“.

Bortset fra hvad familierne har været i stand til at tage med sig på flugten fra Irak, er de afhængige af centeret med hensyn til mad, husly, støtte og rådgivning. Både individuelt og i fællesskab klynger de sig til forventninger om større uafhængighed og frihed i en anden del af verden, der ses som det paradisiske „,endemål“ for fortidens mareridt og nutidens midlertidige ophold. Det er under disse omstændigheder, at de børn, som jeg her vil beskæftige mig med, forsøger at få mening i deres tilværelse.

Børnene er mellem 11 og 14 år gamle. Korte, spontane interview supplerede en traditionel etnografisk og iagttagelsesbaseret metode. Artiklen belyser multikulturelle børneidentiteter og barnet, ikke som en passiv modtager af kulturelle mønstre, men som en refleksiv aktør og formidler af flydende, transkulturelle, transnationale og translinguale processer.

\section{Bevægelse, identitet og „væren-i-mellem“}

Iain Chambers har argumenteret for, at alle identiteter dannes ,i bevægelse“. Identitet, hævder han, er en „migrants historie“ om „stammende overgange“ (Chambers 1994:24). John Berger konkluderer, at man ikke er hjemme i en ting eller på et sted, men ,i et liv, der leves i bevægelse“ (Berger 1984:64). Disse forfattere trækker på det filosofiske begreb om flux og fluiditet for at belyse det erfarende selv. Sagen kan næppe illustreres bedre end med tilværelser, der er ,i bevægelse“" transnationalt.

Den danske antropolog Ann-Belinda Steen Preis (1997) har gjort sig overvejelser over migrantens identitets- og selverfaringer og hævder, at det fysiske og forestillingsmæssige rum migranten bevæger sig inden for, ikke så meget danner et rum for en bevæ- 
gelse hen over et punkt eller over en linie mellem to steder, men derimod danner, hvad hun kalder, et mellem-rum. Hun foreslår, at forskellen mellem et sted eller én kultur og en anden

ikke [er] som en mur, men som et vidtstrakt område af væren-imellem... selve de menneskelige erindringers rumskabelse; en passage gennem erindringens og oprindelsens 'steder', hvorfra der hentes ukendte energier af opfindsomhed og fortætning (Sibony 1991: 11). Denne væren-i-mellem er en proces, en dynamik, et medium mellem en selv og ens oprindelse, et spil snarere end et slutprodukt (Preis 1997:97).

Det er i forhold til sådant et rum af „væren-i-mellem“, at jeg ønsker at beskrive migrantbørns gøremål, ,stemmer“, lege osv., altså netop deres „,opfindsomhedsenergier“. Ud fra

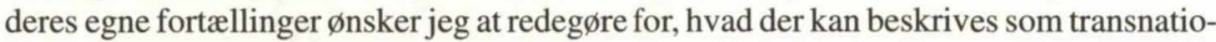
nale ,mellem-rums“ legemliggjorte identiteter.

Jeg håber derved at kunne udbygge forestillingen om migrantbarnet. Et sådant barn er ikke blot et udeltagende, magtesløst subjekt, formet af mangeartede kulturers og sprogs skiftende vinde og strømme, og heller ikke en beholder, der betår af fysiske, sociale og følelsesmæssige behov, som må varetages af andre (voksne). I stedet er migrantbarnet et selvstændigt, kreativt, reflekterende individ, der står centralt i dannelsen af sin egen identitet; en stærk aktør i det, man abstrakt og berøvet enhver menneskelig subjektstatus kalder ,transnationale processer“.

\section{Fire vignetter}

Begrebet vignet betegner en kort, ufuldstændig historie, der i et glimt af en større helhed alligevel får udtrykt den centrale pointe. Det er en miniaturefortælling, der kondenserer en række (om end langt fra alle) biografiske temaer om de folk, den beskriver. Jeg fokuserer på fire forskellige børn. Ved at præsentere en vignet fra hver af deres liv håber jeg at kunne opbygge et større hele. Ikke som et puslespil, hvor hvert tema eller individ udgør en del, der tilsammen fuldender billedet, men som en slags samling af individualiteter, hvis offentlige handlinger og blotlæggelser danner enestående og dog sammenlignelige dele i de transnationale bevægelser og disses lokale og globale bestanddele set fra barnets perspektiv. Ud fra dette udvalg af korte vignetter $\emptyset$ nsker jeg at illustrere fortid, nutid og fremtid, som de udspiller sig, legemliggøres og leges ud i børnenes liv.

\section{Vignet 1: Mellem voksne verdener}

Under feltarbejdet beskrev jeg i mine noter de tanker, der blev kaldt frem af et fotografi af Moreen, en 12-årig pige, hvis korte liv var begyndt i Irak, mens hun nu var i færd med at skabe sig venner i Grækenland. I 1989 var Moreens familie flygtet fra det politiske regimes hårdhændethed, som var en stadig kilde til nyheder og forargelse i Vesten i de tidlige 1990'ere. Efter en rejse på adskillige dage over land og hav ankom hendes familie (mor, far og to ældre brødre) til Grækenland. De agtede at fortsætte rejsen til Amerika, Canada eller Australien i håb om, at et af disse landes ambassader ville blive bevæget af deres ,historie“ og tildele dem asyl. 
I 1995 var de stadig i Grækenland, da det ikke var lykkedes dem at bevæge nogle af disse diplomater til at fatte sympati. Moreen var da tolv og talte flydende græsk. Hun havde et lille netværk af indfødte græske venner på sin egen alder, men nød ikke som sine græske jævnaldrende statsborgerskabets privilegier (for eksempel skolegang). I stedet deltog Moreen i græsk- og engelskundervisning, som flygtningecentret stillede til rådighed med ukvalificeret frivillig arbejdskraft. Overvejelser om at lade sig registrere hos de lokale myndigheder nærede forældrenes frygt for $\mathrm{i}$ bedste fald at $\varnothing$ delægge chancerne for at komme til et andet land, i værste fald at blive deporteret. Mange familier er ude af stand til at forbedre deres situation på grund af dette dilemma.

Det tankevækkende billede viser Moreen iført en t-shirt påtrykt ordene „Mixx Kids on the Move". En overraskende vel-

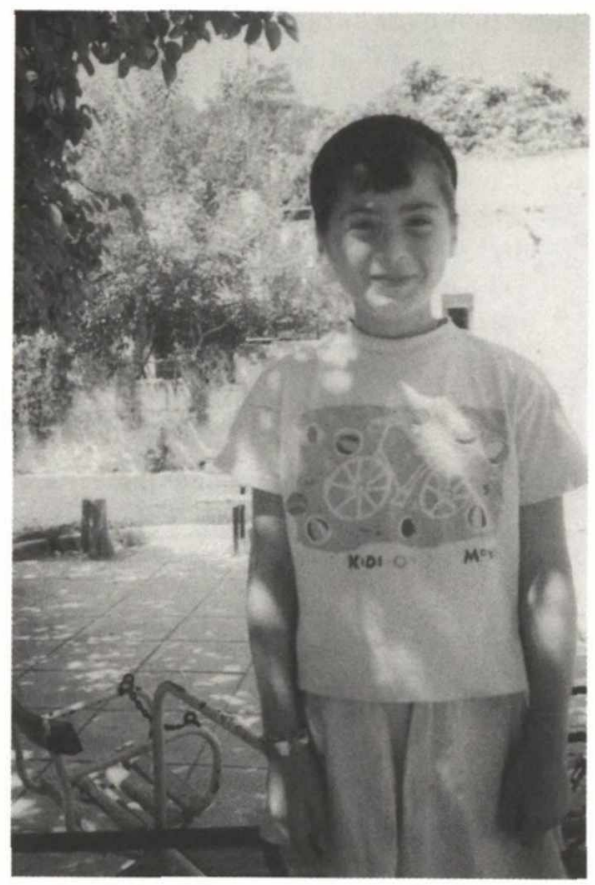
anbragt beskrivelse af et liv „, mellem“ og i overgang. Hun tilhører ikke, i lovens forstand, den nation, hun har levet i nogen tid, og alligevel taler hun sproget flydende og deltager med kompetence i netværk med sine jævnaldrende. Hun kan ikke gå i skole der, men må deltage i en engelskundervisning, der menes at kunne forberede hende til en fremtid, som hendes forældre forestiller sig, hun vil få et andet sted.

Ikke overraskende er Moreens modersmål, arabisk og kaldæisk, blevet ringere, og hun er i fare for, som forældrene udtrykker det, ,,at miste sit sprog og sine skikke“. Det vil sige ikke længere at have direkte forbindelse med sin families kulturelle oprindelse. Det har dog også sine fordele for forældrene, som er rede til at udnytte hendes position som en entusiastisk og kompetent mellemmand; en sproglig og kulturel ,formidler" mellem de ,græske“ og ,irakiske“ voksenverdener hun kun i ringe grad anerkendes formelt i, og ,i-mellem“ hvilke hun alligevel er i stand til at akkumulere betragtelig social kapital.

Når hun af og til nægter at oversætte visse ord og vendinger, bevidst misforstår eller stædigt tilbageholder vigtig information (f.eks. de priser, vægt og mål, som markedssælgere og forretningsekspedienter fremsiger), bidrager det alt sammen til hendes egne personlige forhandlingsmuligheder, der ved enkle byttehandler skaffer hende små begunstigelser såsom slik og tjenester fra sin mor. At hun i denne meget bogstavelige forstand befinder sig i ,mellem-rummet", er ikke en konsekvens af at være lukket ude af både græske og irakiske voksenområder, men udgør snarere disse områders gensidige, praktiske afhængighed af hendes evne til at forbinde dem.

Moreen er tydeligvis underkastet visse sociale betingelser, som følger af de beslutninger, hendes forældre har truffet, for eksempel deres beslutning om at forlade Irak og, om så kun midlertidigt, slå sig ned i Grækenland; deres påbud om, at hun skal følge undervisning i det indfødte sprog (græsk) og engelsk, som de ser som „forberedelse“ til 
hendes ,fremtid“. Deres opfattelse af en nuværende tomhed, som skyldes fraværet af en lovformelig status og visse privilegier, primært skolegang, udfyldes af ,forberedelsen“ til en tid og et sted, der forhåbentlig vil føre status og privilegier med sig. Alligevel kan Moreen finde et geografisk, kulturelt og sprogligt ,liminalt rum“, hvorfra hun kan manipulere og udnytte det af forældrene opfattede tomrum.

\section{Vignet 2: Mellem fortider og fremtider}

Steven var $14 \mathrm{og}$ fortalte af og til historier om det land, hans familie forlod tre år forinden; om bedstemoderen, om slægtninge og om landets præsident „Saddam“. Historierne om fortiden var tydeligt forældrenes erindringer, som var blevet gentaget for ham, så han, ifølge moderen, havde „viden om sin familie og sit land“.

Til trods for mine meget ligefremme forsøg på at fremkalde noget mere fra Steven om hans tidligere liv og forhold, gjorde han mig utålmodigt og på engelsk opmærksom på: „Det ved jeg ikke, jeg er græker nu“. Denne enkle, men faste afvisning var en udfordring af min egen og forældrenes fortælling om, „hvem“ Steven var i fortiden, og hans egen idé om, hvem han var i nutiden.

Et andet talende fotografi afbilder Steven med armen om halsen på sin græske „kæreste“, men de to er adskilt af den lo-

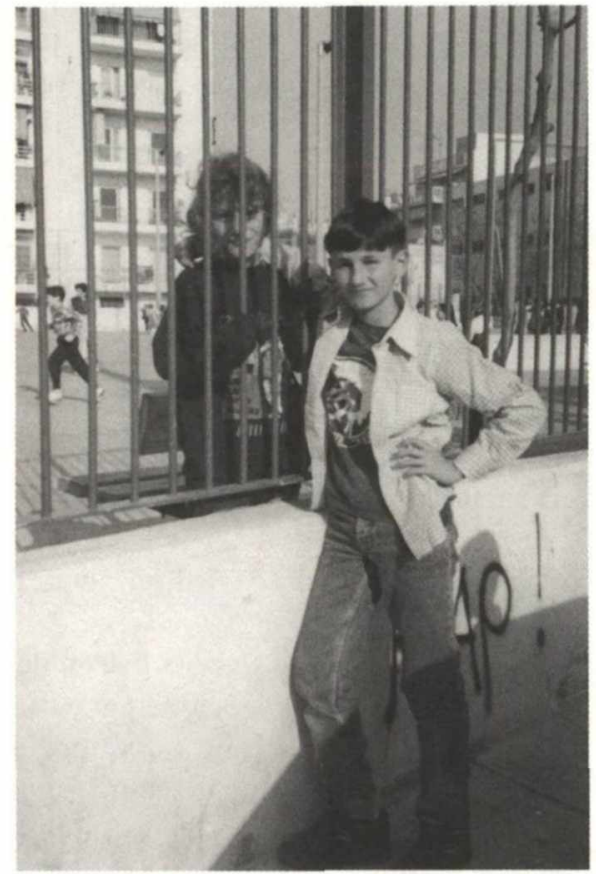
kale skoles gitterværk. Hans arm gennem gitteret billedliggør, at han ikke blot har hånden, men hele armen inde i en kultur. Det er en væsentlig del af ham selv, men han er stadig langt fra at være lukket helt ind. Selvom han er udelukket fra den skole, kæresten går i, er der tilstrækkelig social, kulturel og sproglig gennemslagskraft til, at en sådan forhindring ikke udgør et for stort problem for romantik og venskab. Kulturelle grænser viser sig ofte i mindre grad at være stenmure end gitterhegn med store huller!

Som det er velkendt fra etniske minoritetssamfund mange steder i verden, er det andengenerationsmigranterne, der mest effektivt gennembryder de sociale grænser, som almindeligvis holder førstegenerationsmigranterne indelukket $\mathrm{i}$ ghettoer. Ikke overraskende har de irakiske migrạntbørn da også udviklet og vedligeholdt forbindelser med de lokale. Dette til trods for de forventninger, de nærer til de lande, hvor de siden skal rejse hen. Steven er begejstret over udsigten til et liv hinsides sin nuværende situation og bekymringer. Skønt historier om soldater, våben og „Saddam“ genkaldes fra moren og fra det land, han tidligere levede i, har de måttet vige for den amerikanske basketballhelt 
„Magic“ Johnsons dygtighed, ,et stort hus“, ,,stor bil“ og ,dejlige ting“, der var blandt alt det, han ville få, når han kom derhen.

Dette fjerne håb og denne fantasi er blevet til virkelighed: Steven tog sammen med sin familie til Chicago en uge før, jeg færdiggjorde mit feltarbejde.

\section{Vignet 3: Mellem virkelige og imaginære steder}

Moreen og Steven er ikke alene i dette „mellem-rum“. Her finder vi også Arshak på 12. Fantasiknive, som hans små tætte knytnæver holder fast om, legemliggør fortid og minder, så de bliver fysisk tilstedeværende. „Dig slår jeg ihjel nu, bagefter slår vi de andre ihjel", kan han i leg hviske til mig. Han besidder imaginære „geværer" og ethvert tænkeligt torturredskab. Han ligger på lur efter mig, sniger sig ind på mig og skærer halsen over på mig på samme måde, som han ,vil slå Saddam ihjel på“, som han siger det. „Tha kopso stoma, tha kopso stoma", plejer han at gentage på græsk (,Jeg vil skære halsen over på ham, jeg vil skære halsen over på ham").

„Det her er min bil“", griner han en dag. „Jeg tage Canada, nu“. Den udtjente traktor - et farligt, rustent vrag af ubevægeligt jern i vejsiden nær flygtningelejren - er Ar-

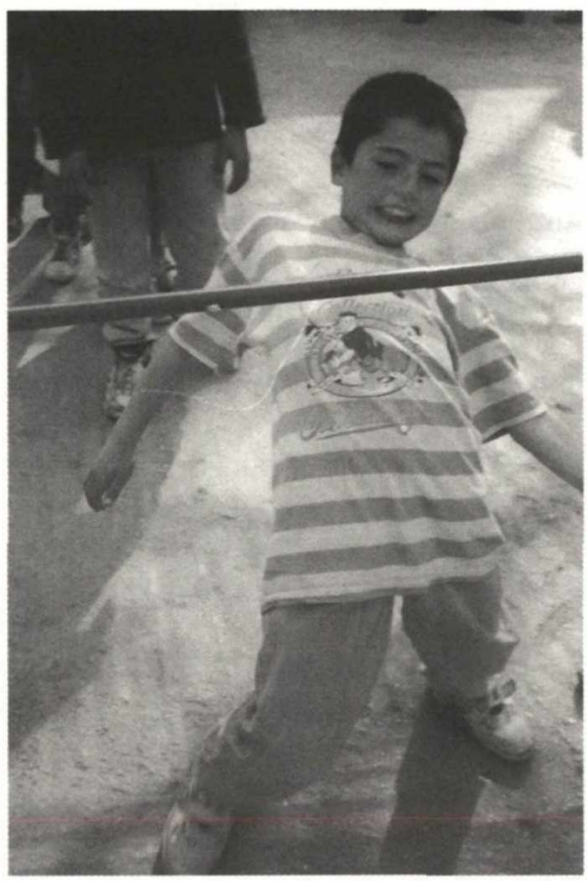
shaks „hemmelighed“, betror han mig en dag. „Her sidder jeg, brrm, tage du også Canada? Jeg er i Canada nu, haha, dejligt“. Sætninger afbrudt af latterkramper over det komiske ved at nå det liv, hans moder konstant har lovet, i sådan en tingest.

Arshak tilbragte mange lykkelige timer med at knuge om rattet og lege med gearstangen, et befordringsmiddel for fantasi og flugt, ikke mindst fra hans højtråbende jævnaldrende. ,Han tage Canada“, lo de spottende, når jeg spurgte, hvor han var. Det betød, at han sad på sin traktor.

Måske udtrykker traktoren en falsk forhåbning. Men hvis den udtrykker håb, gør den det ironisk. Et immobilt køretøj rettet mod imaginære andre steder indeholder sin egen selvmodsigelse og latterlighed. For Arshak var traktoren i bogstavelig forstand et grinagtigt vrag, der fysisk ikke kunne komme nogen steder. Men i fantasien: Canada. 


\section{Vignet 4: Mellem familie og offentlighedspersoner}

Rimon er en 14-årig dreng, hvis barndom er et tydeligt eksempel på „væren-i-mellem“. Ikke så meget mellem tider og steder, men mellem hans families situation som fordrevet og hans fremstilling af deres fordrivelse. Rimon har af ambassaden fået til opgave at beskrive sin families situation og erfaringer - et af standardkravene til en asylansøgning. Rimons engelsk er bedre end forældrenes, hvorfor han også er blevet bedt om at oversætte deres ord. Han fortæller således om opgaven:

Jeg skrev om vort liv i Irak... om Saddam. Han er meget ond... politiet, de tog min onkel til jeg ved ikke hvor. Saddam er et svin... Jeg skrev det [på ansøgningen]. Så vi forlod Irak. Jeg vil aldrig tilbage dertil. Vi vil til Australien. Men her på ambassaden vil de ikke tro på os... hvorfor tror de ikke på os? (trækker på skulderen). Nu skriver vi for [sic til] FN [...] Nu vil jeg ikke rejse... Jeg kan li' Grækenland. Jeg har venner... men går ikke i skole... Jeg ved ikke hvad der kommer til at ske (ler).

Rimons indirekte involvering med ambassadefunktionærerne giver ham på en paradoksal måde en stor handleevne i forhold til at kunne skaffe sig en mulig overgang til et andet liv og et andet sted. Familiens kollektive „vi“ $\emptyset n s k e r$ at forlade Grækenland, men Rimon gør det ikke selv. I kraft af forældrenes insisteren fremstiller beskrivelsen ham som en migrant og flygtning, en status, han er usikker på ud fra sin egen ,plads“ i $i$ verden. Han vil blive i Grækenland, og dog peger det, at han ,ikke ved, hvad der kommer til at ske“, på den magtesløshed, han oplever ved at være underlagt forældrenes og ambassadefunktionærernes beslutninger. Den tankegang, som indfanges af hans mundtlige „snapshot", får én til at tænke på en palet, hvorpå hans tilværelses forskellige sociale og politiske farvetoner blandes i tider og steder mellem de hjemlige relationers mindste detaljer og den internationale politiks scene. Det er en blanding og kompleksitet, der måske bedre kommer frem $\mathrm{i}$ tvetydigheden $\mathrm{i}$ hans afsluttende kommentar og latter.

Andre mere overordnede iagttagelser af denne gruppe som helhed illustrerer de pragmatiske tilpasninger som særlige kontekster kræver. For eksempel ændres deres navne, når de er sammen med lokale græske venner, fra Rimon, Arshak og Moreen til „Marcos“, „Vassilios“ og „Maria“, typiske græske navne. Fra det ene øjeblik til det andet finder der sprogskift sted, frem og tilbage mellem kaldæisk, arabisk, græsk og engelsk.

\section{At gen-kende og inkorporere "mellem-rum"}

Som denne vignetmontage antyder, stimulerer børnenes brug af situationer, tanker, følelser og fantasi deres selvopfattelse i forhold til steder og tider. Steder og tider er markante begreber og nyttige redskaber for børn i deres fors $\emptyset \mathrm{g}$ på at placere og identificere sig selv. Personlige anstrengelser for at placere sig i en verden i bevægelse stimulerer den kreative evne til for disse børn bogstaveligt at kortlægge sig selv i en global sammenhæng. De forandrer tings og situationers betydninger for at gøre andre ting, andre steder, andre situationer, andre identiteter mulige. Det er, hvad udtrykket ,opfindsomhedsenergier“" kan strækkes til at omfatte (jf. Preis 1997). Erfaring og fortælling er således kropsliggjort, og de identiteter, de udtrykker, er lige så meget i den kropslige praksis som i den kognitive 
tænkning. Hvert af børnene inkorporerer minder og forventninger, som giver fortid og fremtid, nostalgi og håb til nutidens sociale og kulturelle konturer.

Kulturer og sprog løber sammen og glider fra hinanden, mødes og skilles i de daglige interaktioner mellem familie, venner og andre. Det påvirker de hjemlige spændinger for børn, hvis forhold til familie og venner ikke blot kræver et forskelligt sæt af adfærdsmåder, men forskelligt sprog og måde at være til på. Truslen om modersmålstab til fordel for græsk og engelsk beklages af forældrene, men erhvervelsen af et andet sprog og dets praktiske betydning menes at være et nødvendigt, om end smerteligt, bytte under de nuværende omstændigheder.

Børn og barndomme bliver normalt anskuet i faste lokaliseringer, og børnenes sociale og kulturelle identiteter navngives og teoretiseres i overenstemmelse hermed: børn i nord, børn i syd, britiske børn, danske børn, japanske børn, amerikanske børn osv. (jf. Whiting \& Edwards 1988). Det er måske forståeligt og velbegrundet i visse henseender, men man kan ikke tage udgangspunkt i, at alle barndomme er kulturelt „fastspændte“. Kulturer er ikke længere som mosaikker, men som strømme (Hannerz 1993:68), og derfor kan man sige det samme om disse „kulturers“ børn.

De transnationale bevægelser af mennesker, ting og ideer sammenfatter dynamikken i disse processer, samtidig med at de påvirker og påvirkes af menneskelige interaktioner over hele verden. Børns og barndommes placering i disse processer må imidlertid udforskes og begrebsliggøres på en mere subtil måde, end de velmenende internationale organisationer har gjort det med deres implicitte konstruktion af det ,globale barn“. Omvendt er heller ikke kritikken af denne konstruktion med dens henvisninger til kulturelt specifikke barndomme tilstrækkelig. Migrantbørn eller barndomme, der „,bevæger sig“ kulturelt, udfordrer begge disse betragtningsmåder. Sådanne børn er hverken på en afgørende måde fra særegne kulturer i den traditionelle forstand, ej heller kan de reduceres til en globaliseret homogenitet. Dertil kommer, at de ikke blot befinder sig ,i-mellem“ kulturer, de befinder sig også ,i-mellem“ lokale og globale barndomsopfattelser.

Fra et rum ,i-mellem“ fremkommer børneidentiteter ved at forme sig efter og udfordre andres ,tekster“ om fordrivelse og de kollektive krav til, hvad erindringer og fremtider bør være. For eksempel bliver de områder, børnenes forældre frygter som „det an$\operatorname{det}^{\text {", }}$, herunder den kulturelle oprindelse, erindrede fortider og en uønsket fremtid, blot kontekstuelle dele af børnenes selv'er i nutiden, selvom de tilsyneladende er modsætningsfulde og uden sammenhæng i forhold til andre kontekster. Efterhånden som de bliver bevidste om sociale, kulturelle og sproglige forhold, konstruerer børnene deres identiteter i forhold til de forskellige (og modsatrettede) dimensioner ved tid og rum, som deres livsvilkår giver dem mulighed for at tænke med.

\section{Afsluttende tanker}

Denne artikel har søgt at betragte børn i en kontekst af faktisk og forestillet social, kulturel og sproglig bevægelse. De jonglerer og forliger modsatte og ofte konkurrerende identiteter og forestillinger tillige med sproglige og kulturelle kompetencer. Kort sagt belyser artiklen, hvorledes børn påvirkes af og selv påvirker den samling af indflydelseskilder, som bidrager til at skabe bevidsthed om deres egen kalejdoskopiske bevægelse og de følger, denne bevægelse har for identitetsdannelsen. I samfundsvidenskaberne såvel som i 
populære forestillinger er børn traditionelt blevet betragtet som „kulturbeholdere“, der bærer kulturelle traditioner videre. På denne komplekse og vanskelige arena for migration, sproglige og kulturelle sammenfald samt opløsning og opsplitning skal barnet teoretisk set gentænkes som en agent i kulturel produktion. Som agenter i deres egen selvproduktion bevæger og blander børn ,kulturer" i det virkelige liv. Ved at studere børns ,,agency“ i situationer af ,,væren-i-mellem“ kan vi hæve vores viden om processer af kulturel blanding og bevægelse til et andet analytisk niveau.

„Hybridbarnet“ er ikke nødvendigvis kun et, der bevæger sig hen over verdenen og ind og ud af kulturer, og som fremmaner flydende identiteter, mens det flytter omkring. Kulturelle fortætninger, som indføres i og findes inden for mere tydeligt definerede lokaliteter, tvinger os til at tage hensyn til de forskelligheder, som griber ind i, $\emptyset$ ver indflydelse på og farver alle børns bevidsthed. Børn såvel som voksne er i en vis forstand ,i mellem“" kulturer, tider og steder på forskellige måder; alle bevæger de sig, forestiller sig og fortæller om sig selv, at de befinder sig i ,,mellem-rum“, og alle undersøger og trækker på deres oplevelser af disse mellemrum for at kunne placere og identificere sig selv. Vi kan ikke gå ud fra, at enten det „globale“ eller det ,kulturspecifikke“ barn er brugbare begreber til at forstå, hvorledes børn tænker på sig selv i forhold til identitet, med mindre vores tænkning giver plads til tilstrækkelige (og kontekstualiserede) „strømme“ mellem begge opfattelser med henblik på såvel individuelle liv som generel teoridannelse.

\section{Litteratur}

Berger, J.

1984 And Our Faces, My Heart, Brief as Photos. London: Writers and Readers.

Boyden, J. 1990 Childhood and the Policy Makers: A Comparative Perspective on the Globalisation of
Childhood. I: A. James \& A. Prout (red.): Constructing and Reconstructing Childhood. London: Falmer.

Chambers, I.

1994 Migrancy, Culture and Identity. London: Routledge.

Ennew, J.

1986 The Sexual Exploitation of Children. Cambridge: Polity Press.

Fardon, R. (red.)

1995 Introduction. I: R. Fardon: Counterworks: Managing the Diversity of Knowledge. London: Routledge.

Hannerz, U.

1993 The Cultural Role of World Cities. I: A. P. Cohen \& K. Fukui (red.): Humanizing the City? Edinburgh: Edinburgh University Press.

Moore, $\mathrm{H}$.

1996 What is Social Knowledge for? London: Routledge.

Preis, A. B. Steen

1997 Capsized Identities and Contracted Belonging among Sri Lankan Tamil Refugees.

I: K. Fog Olwig \& K. Hastrup (red.): Siting Culture: The Shifting Anthropological Object. London: Routledge. 
Whiting, B. B. \& C. P. Edwards

1988 Children of Different Worlds. Cambridge, MA: Harvard University Press. 